\title{
Replication Error
}

National Cancer Institute

\section{Source}

National Cancer Institute. Replication Error. NCI Thesaurus. Code C19600.

A Replication Error results from the covalent addition of an incorrect nucleotide subunit, or the lack of addition of a nucleotide subunit, during polymerization of the growing newly synthesized DNA strand during replication. $(\mathrm{NCl})$ 